Science Fiction, Disruption

and Tourism 


\section{THE FUTURE OF TOURISM}

Series Editors: Ian Yeoman, Victoria University of Wellington, New Zealand and Una McMahon-Beattie, Ulster University, Northern Ireland, UK

Some would say that the only certainties are birth and death; everything else that happens in between is uncertain. Uncertainty stems from risk, a lack of understanding or a lack of familiarity. Whether it is political instability, autonomous transport, hypersonic travel or peak oil, the future of tourism is full of uncertainty but it can be explained or imagined through trend analysis, economic forecasting or scenario planning.

This new book series, The Future of Tourism, sets out to address the challenges and unexplained futures of tourism, events and hospitality. By addressing the big questions of change, examining new theories and frameworks or critical issues pertaining to research or industry, the series will stretch your understanding and generate dialogue about the future. By adopting a multidisciplinary perspective, be it through science fiction or computer-generated equilibrium modelling of tourism economies, the series will explain and structure the future - to help researchers, managers and students understand how futures could occur. The series welcomes proposals on emerging trends and critical issues across the tourism industry and research. All proposals must emphasise the future and be embedded in research.

All books in this series are externally peer-reviewed.

Full details of all the books in this series and of all our other publications can be found on http://www.channelviewpublications.com, or by writing to Channel View Publications, St Nicholas House, 31-34 High Street, Bristol BS1 2AW, UK. 
THE FUTURE OF TOURISM: 6

Science Fiction,

Disruption and

Tourism

Edited by

Ian Yeoman,

Una McMahon-Beattie and

Marianna Sigala

CHANNEL VIEW PUBLICATIONS

Bristol $•$ Jackson 
DOI https://doi.org/10.21832/YEOMAN8670

Library of Congress Cataloging in Publication Data

A catalog record for this book is available from the Library of Congress.

Names: Yeoman, Ian, editor. | McMahon-Beattie, Una, editor. | Sigala, Marianna, editor.

Title: Science Fiction, Disruption and Tourism/Edited by Ian Yeoman, Una McMahon-Beattie and Marianna Sigala.

Description: Bristol, UK; Blue Ridge Summit, PA: Channel View Publications, 2022. | Series: The Future of Tourism: 6 | Includes bibliographical references and index. | Summary: "This book examines science fiction's theoretical and ontological backgrounds and how science fiction applies to the future of tourism. Focusing on disruption, sustainability and technology, it brings a new theoretical paradigm to the study of tourism in a post COVID-19 world and can be used to explore, frame and even form the future of tourism"- Provided by publisher. Identifiers: LCCN 2021036438 (print) | LCCN 2021036439 (ebook) | ISBN 9781845418663 (paperback) | ISBN 9781845418670 (hardback) | ISBN 9781845418687 (pdf) | ISBN 9781845418694 (epub)

Subjects: LCSH: Tourism-Planning. | Contents tourism. | Literary journeys. | Science fiction. Classification: LCC G155.A1 S354 2022 (print) |

LCC G155.A1 (ebook) | DDC 306.4/819—dc23

LC record available at https://lccn.loc.gov/2021036438

LC ebook record available at https://lccn.loc.gov/2021036439

British Library Cataloguing in Publication Data

A catalogue entry for this book is available from the British Library.

ISBN-13: 978-1-84541-867-0 (hbk)

ISBN-13: 978-1-84541-866-3 (pbk)

\section{Channel View Publications}

UK: St Nicholas House, 31-34 High Street, Bristol, BS1 2AW, UK. USA: Ingram, Jackson, TN, USA.

Website: www.channelviewpublications.com

Twitter: Channel_View

Facebook: https://www.facebook.com/channelviewpublications

Blog: www.channelviewpublications.wordpress.com

Copyright (C) 2022 Ian Yeoman, Una McMahon-Beattie, Marianna Sigala and the authors of individual chapters.

All rights reserved. No part of this work may be reproduced in any form or by any means without permission in writing from the publisher.

The policy of Multilingual Matters/Channel View Publications is to use papers that are natural, renewable and recyclable products, made from wood grown in sustainable forests. In the manufacturing process of our books, and to further support our policy, preference is given to printers that have FSC and PEFC Chain of Custody certification. The FSC and/or PEFC logos will appear on those books where full certification has been granted to the printer concerned.

Typeset by Nova Techset Private Limited, Bengaluru and Chennai, India. 